\title{
PENINGKATAN PEMASARAN SUSU KEDELAI BUBUK \\ MELALUI STRATEgI BAURAN: Studi Kasus Pada Pabrik Susu Kedelai Kadungora di Desa Kadungora, Kecamatan Kadungora, Kabupaten Garut
}

\author{
Dini Rochdiani dan Hesty Nurul Utami \\ Jurusan Sosial Ekonomi Pertanian Fakultas Pertanian \\ Universitas Padjadjaran Bandung
}

\begin{abstract}
ABSTRAK. Susu kedelai sebagai alternatif pilihan pemenuhan kebutuhan susu bagi masyarakat sebagai pengganti susu sapi belum tersosialisasi dengan baik. Pabrik Susu Kedelai Kadungora dalam pengembangan usahanya melakukan strategi integrasi ke depan dan strategi penetrasi pasar. Strategi tersebut dapat dilakukan dengan cara mempertahankan kualitas produk dan tingkat harga, memperbaiki sistem kerja sama dengan agen distributor, mengangkat tenaga penjual dalam perusahaan, mengorganisasi tugas dan wewenang staf manajemen perusahaan lebih spesifik dan segera mendapatkan investor baru. Selain itu, perusahaan perlu melakukan strategi perbaikan manajemen organisasi perusahaan terutama yang berkaitan dengan jalinan kerja dengan investor atau menggunakan jasa perbankan untuk menyelesaikan masalah keuangan yang berdampak negatif pada sistem pemasaran produk.
\end{abstract}

Kata Kunci: Bauran pemasaran, susu kedelai, strategi, analisis lingkungan perusahaan

\section{MARKETING PROMOTION OF POWDER SOY MILK THROUGH MIXING STRATEGY : Case Study at Soy Milk Factory in Kadungora, The Subdistrict of Kadungora, The Regency of Garut}

\begin{abstract}
Soy milk as one of the alternative choice to fulfill Indonesian people milk necessity to replace dairy milk has not been socialized well nowadays. The firm Susu Kedelai Kadungora is to develop the business to do forward integration strategy and product penetration strategy. That strategies can to do is the way to maintain the quality of their product and also maintain the product price rate, reform cooperation system with agent as product distributor, restructure the personal selling activity in retail, organize job description and job authority of staff management specifically and find new investor.Besides that, the firm need reformation the organization management strategy particularly concerning investor relationship or try the banking service to solve the financial problem which gives a negative impact in the product marketing system.
\end{abstract}

Key word: Marketing mix, soy milk, strategy, company surrounding analysis 


\section{PENDAHULUAN}

Kedelai merupakan tanaman pangan terpenting ketiga setelah padi dan jagung di Indonesia. Saat ini produk hasil olahan baru dari kedelai yang mulai banyak diproduksi di Indonesia adalah jenis susu kedelai, baik jenis susu kedelai bubuk maupun susu kedelai cair. Salah satu hal penting dari susu kedelai ini adalah bahwa susu kedelai dapat dijadikan sebagai alternatif pengganti susu sapi yang saat ini menjadi pilihan konsumsi susu masyarakat.

Ada alasan mengapa perlu adanya produk susu jenis lain selain susu sapi sebagai alternatif pilihan bagi masyarakat untuk memenuhi kebutuhan gizi akan susu. Konsumsi susu masyarakat Indonesia selama 30 tahun terakhir, trend peningkatan konsumsinya berjalan sangat lambat. Jika dibandingkan dengan tiga negara tetangga di kawasan Asia Tenggara, yaitu Malaysia dan Thailand, tingkat konsumsi susu masyarakat Indonesia merupakan yang paling rendah. Tingkat konsumsi penduduk Indonesia masih sekitar 7 liter/kap/tahun, negara Malaysia sudah mencapai 21 liter/kap/tahun, dan Thailand 24 liter/kap/tahun. Bahkan pada tahun 2004, rata-rata orang Indonesia hanya mengkonsumsi susu setengah gelas seminggu atau setara dengan 14 gram/hari, yang artinya asupan protein yang sangat menentukan tinggi badan seseorang masih sangat rendah. Indikasi yang menyebabkan rendahnya tingkat konsumsi susu masyarakat Indonesia adalah banyak masyarakat Indonesia yang masih menganggap bahwa minum susu hanya untuk balita, selain itu di Indonesia susu masih dianggap sebagai barang lux yang harganya mahal, serta adanya rasa takut dengan masalah lactose intolerance.

Ketakutan terjadinya 7 lactose intolerance dapat dihilangkan karena susu kedelai berkadar laktosa rendah atau sama sekali bebas laktosa. Selain itu, susu kedelai mampu memberikan asupan gizi yang tidak kalah lengkap seperti yang terkandung dalam susu sapi, baik dari segi kandungan protein maupun kandungan asam amino. Jika susu kedelai mampu dijadikan alternatif pengganti susu sapi, maka produksi susu kedelai ini selayaknya ditingkatkan. Dalam hal ini yang berperan penting adalah industri pengolahan atau agroindustri yang mengolah biji kedelai menjadi bentuk susu kedelai.

Pabrik Susu Kedelai yang berlokasi di Desa`Kadungora, Kecamatan Kadungora, Kabupaten Garut merupakan satu-satunya industri kecil berbasis agroindustri berbadan hukum di Kabupaten Garut yang memproduksi susu kedelai jenis bubuk (soy milk powder). Meskipun skala usahanya masih tergolong industri kecil dan komersialisasi produk baru dimulai tahun 2004, tapi agroindustri ini telah mampu mengupayakan diproduksinya susu kedelai jenis bubuk yang masih jarang ada di pasaran.

Peluang industri susu kedelai bubuk di masa mendatang diperkirakan memiliki prospek usaha yang baik. Karena profil konsumsi susu di Indonesia menunjukkan bahwa susu putih cair hanya memberikan kontribusi sebesar 17,9 persen dari total konsumsi susu putih. Sementara 82 persen sisanya merupakan konsumsi susu putih bubuk. Data jumlah produksi susu bubuk nasional yang diperoleh dari Badan 
Pusat Statistik menunjukkan peningkatan jumlah produksi yang signifikan, yaitu meningkat sebesar $75.444 .946 \mathrm{~kg}$ atau 35,72 persen selama tiga tahun terakhir dari tahun 2004-2006, yang artinya permintaan terhadap susu bubuk terus meningkat.

Kenyataan bahwa susu kedelai dapat dijadikan alternatif pilihan pengganti susu sapi belum tersosialisasi dengan baik di masyarakat. Hal ini dapat dilihat pada kelangsungan sistem pemasaran produk susu kedelai bubuk produksi pabrik susu kedele kadungora yang tidak optimal sesuai dengan target perusahaan. Pabrik Susu Kedele Kadungora sebagai produsen produk susu kedelai bubuk yang baru memasarkan produknya selama hampir empat tahun ini masih harus berusaha keras untuk mencapai penjualan produk yang optimal. Hal ini ditunjukkan dengan jumlah volume penjualan produk pada periode bulan Mei 2006 sampai bulan Mei 2007 yang mengalami penurunan drastis mencapai 86,22 persen.

Optimalisasi pemasaran berperan penting dalam kendala yang dialami perusahaan dalam memasarkan produk. Menurut Djaslim Saladin (2005: 3), pemasaran merupakan suatu sistem total dari kegiatan bisnis yang dirancang, untuk merencanakan, menentukan harga, promosi, dan mendistribusikan barangbarang yang dapat memuaskan keinginan dan mencapai pasar sasaran serta tujuan perusahaan.

Berdasarkan fenomena tesebut, maka penelitian ini dilakukan untuk melihat gambaran bauran pemasaran (marketing mix) yang selama ini dilakukan oleh Pabrik Susu Kedelai Kadungora, meliputi product, price, place dan promotion. Berdasarkan komponen-komponen bauran pemasaran dapat dilihat sejauh mana optimalisasi marketing yang telah dilakukan perusahaan. Selanjutnya dianalisis pula strategi bauran pemasaran yang seharusnya dilakukan oleh perusahaan sehingga kendala pemasaran yang selama ini dihadapi oleh perusahaan dapat diatasi.

\section{METODE PENELITIAN}

Penelitian ini menggunakan metode penelitian studi kasus, yaitu menggambarkan secara rinci dengan tekanan pada situasi keseluruhan mengenai proses atau urut-urutan suatu kejadian sehingga memberikan kajian yang mendalam dengan pendekatan struktural. Objek yang dikaji dari penelitian ini adalah bentuk strategi bauran pemasaran (marketing mix) produk susu kedelai bubuk (soy milk powder) dihubungkan dengan volume penjualan produk. Adapun yang menjadi unit analisis dalam penelitian ini adalah Pabrik Susu Kedelai Kadungora sebagai satu-satunya pengolah agroindustri biji kedelai menjadi susu kedelai di Desa Kadungora, Kecamatan Kadungora, Kabupaten Garut yang masih berproduksi sampai sekarang (tahun 2007).

Data, informasi dan pengetahuan yang dikumpulkan terdiri atas data primer dan data sekunder. Data primer diperoleh berdasarkan observasi, diskusi, dan wawancara dengan pihak manajemen perusahaan sebagai produsen produk meliputi : direktur utama perusahaan, manajer keuangan, manajer produksi, 
manajer bagian umum, staf bagian pembelanjaan serta pelanggan dengan teknik pengambilan responden yang dilakukan secara sengaja (purposive). Sementara itu, data sekunder diperoleh dari studi kepustakaan, dokumen tertulis, makalah, dan berbagai laporan yang terdapat di berbagai instansi serta dari studi literatur lain yang terkait dengan penelitian.

Penelitian ini dianalisis secara deskriptif dengan menggunakan model analisis strategi secara komprehensif menurut konsep perumusan strategi Fred R. David, dengan formulasi sebagai berikut :

\section{Matriks Eksternal Factor Evaluation (EFE) dan Matriks Internal Factor Evaluation (IFE)}

Tahapan kerja membuat matriks EFE dan IFE adalah sebagai berikut :

a. Membuat daftar critical success factors (faktor-faktor utama yang mempunyai dampak penting pada kesuksesan atau kegagalan bauran pemasaran yang dilakukan perusahaan) untuk faktor ekstenal yang mencakup oppotunities (peluang) dan threats (ancaman), sedangkan untuk factor internal mencakup kekuatan (strength) dan kelemahan (weakness) masing-masing lima faktor.

b. Menentukan bobot (weight) dilakukan dengan jalan mengajukan faktor-faktor strategis eksternal dan internal pada pihak manajemen perusahaan dengan menggunakan metode paired comparison (Rangkuti, 2005). Metode tersebut untuk memberikan penilaian terhadap bobot setiap faktor penentu eksternal dan internal.

c. Untuk menentukan bobot setiap variabel digunakan skala 1,2, dan 3. Skala yang digunakan untuk pengisian kolom adalah:

$1=$ jika indikator horizontal kurang penting daripada indikator vertikal

$2=$ jika indikator horizontal sama penting daripada indikator vertikal

$3=$ jika indikator horizontal lebih penting daripada indikator vertikal

Bobot setiap variabel diperoleh dengan menentukan nilai setiap variabel tersebut terhadap jumlah nilai keseluruhan variabel, dengan rumus:

\section{Keterangan :}

$$
A_{i}=\frac{x_{i \ldots n}}{\sum_{i=1} x_{i}}
$$

$A_{i}=$ Bobot variabel ke- $i$

$\mathrm{i}=\mathrm{A}, \mathrm{B}, \mathrm{C}, \ldots, \mathrm{n}$

$\mathrm{X}_{\mathrm{i}}=$ Total nilai variabel

$\mathrm{n}=$ Jumlah variabel 
Tabel 1. Penilaian Bobot Faktor Strategis Eksternal/Internal Perusahaan

\begin{tabular}{cccccc}
\hline $\begin{array}{c}\text { Faktor Strategis } \\
\text { Eksternal/ } \\
\text { Internal }\end{array}$ & A & B & C & $\ldots$ & Total \\
\hline A & & & & & \\
\hline B & & & & \\
\hline C & & & \\
\hline$\ldots$ &
\end{tabular}

Keterangan :

$\mathrm{A}, \mathrm{B}, \mathrm{C}, \ldots, \mathrm{n}=$ Faktor-faktor peluang dan ancaman utama

Sumber : Kinnear, 1991.

Penilaian atas hasil akhir perhitungan bobot suatu faktor adalah, bila bobot bernilai nol artinya faktor tidak berpengaruh; bobot bernilai $>0-0,05$ faktor berpengaruh kecil; bobot bernilai > 0,05-0,1 faktor cukup berpengaruh; bobot bernilai $>0,1$ faktor berpengaruh besar (sangat besar pengaruhnya).

Tabel 1. selanjutnya akan memberikan penjelasan besarnya pengaruh faktor internal maupun eksternal perusahaan terhadap bauran pemasaran susu kedelai bubuk produksi pabrik susu kedelai Kadungora.

d. Tentukan rating setiap critical succes factors antara 1 sampai 4 , di mana $1=$ major weakness, $2=$ minor weakness, $3=$ minor strenght, dan $4=$ major strenght. Penilaian rating untuk faktor peluang dan kekuatan bersifat positif, misalnya peluang atau kekuatan yang semakin besar diberi rating 4, tetapi bila peluangnya atau kekuatannya sangat kecil diberi rating 1 . Penilaian rating untuk faktor ancaman atau kelemahan adalah sebaliknya, misalnya bila ancaman atau kelemahan sangat besar nilai ratingnya 1 dan bila ancamannya atau kelemahannya sangat kecil ratingnya 4. Menentukan rating dilakukan dengan mengajukan faktor-faktor strategis eksternal dan internal pada pihak manajemen perusahaan, berdasarkan faktor-faktor eksternal dan internal yang mempengaruhi strategi bauran pemasaran produk susu kedelai bubuk yang dilakukan perusahaan dan kondisi perusahaan. Nilai bobot dikalikan dengan nilai ratingnya untuk mendapatkan skor semua critical success factors.

e. Semua skor dijumlahkan untuk mendapatkan skor total bagi faktor-faktor eksternal dan internal yang mempengaruhi bauran pemasaran.

Faktor-faktor eksternal yang dinilai adalah faktor lingkungan makro dan faktor lingkungan mikro. Skor total 4,0 mengindikasikan bahwa perusahaan merespon dengan sangat baik peluang-peluang yang ada dan menghindari ancaman-ancaman di pasar industrinya dalam menentukan bauran pemasaran. Skor total sebesar 1,0 menunjukkan bahwa perusahaan tidak memanfaatkan 
peluang-peluang yang ada atau tidak menghindari ancaman-ancaman eksternal. Faktor-faktor internal yang dinilai adalah faktor produksi dan penjualan, keuangan, SDM, struktur organisasi perusahaan, dan litbang. Nilai rata-rata adalah 2,5. Jika nilainya di bawah 2,5 mengindikasikan bahwa secara internal, perusahaan adalah lemah, sedangkan nilai yang berada di atas 2,5 menunjukkan posisi internal yang kuat.

Tabel 2. Matriks Evaluasi Faktor Eksternal/ Matriks Evaluasi Faktor Internal

\begin{tabular}{ccccc}
\hline \multirow{2}{*}{ No } & Faktor Kunci & Bobot & Rating & Skor \\
\cline { 2 - 4 } & $\begin{array}{c}\text { Peluang/ } \\
\text { Kekuatan }\end{array}$ & $\left(\mathrm{A}_{\mathrm{i}}\right)$ & $\left(\mathrm{B}_{\mathrm{i}}\right)$ & $\left(\mathrm{A}_{\mathrm{i}} \times \mathrm{B}_{\mathrm{i}}\right)$ \\
\hline 1. & & & \\
\hline 2. & & & \\
\hline$\ldots$ & & & \\
\hline & $\begin{array}{c}\text { Ancaman/ } \\
\text { Kelemahan }\end{array}$ & & \\
\hline 1. & & & \\
\hline 2. & & & $\sum\left(\mathrm{A}_{\mathrm{i}} \times \mathrm{B}_{\mathrm{i}}\right)$ \\
\hline$\ldots$ & & & \\
\hline
\end{tabular}

Tabel 2. merupakan matriks hasil eksternal/internal factors evaluation yang selanjutnya akan memberikan gambaran mengenai efektifitas perusahaan dalam menjalankan strategi bauran pemasaran produk susu kedelai bubuk dalam memanfaatkan peluang-peluang yang ada dan menghindari ancamanancaman eksternal yang dihadapi perusahaan saat ini. Jika skor faktor $>1,00$, maka maka perusahaan efektif dalam menjalankan strategi bauran pemasaran produk susu kedelai bubuk dalam memanfaatkan peluang-peluang yang ada dan menghindari ancaman-ancaman eksternal yang dihadapi perusahaan saat ini.

\section{Matriks Internal Eksternal (IE)}

Matriks IE digunakan untuk memposisikan komponen-komponen internal dan eksternal yang mempengaruhi bauran pemasaran perusahaan ke dalam matriks (sembilan sel). Matriks IE terdiri atas dua dimensi, yaitu total skor dari matriks IFE pada sumbu $X$ dan total skor dari matriks EFE pada sumbu $Y$.

Pada sumbu $X$ dari matriks $I E$, ada tiga skor, yaitu skor 1,0-1,99 menyatakan bahwa posisi internal adalah lemah; skor 2,0-2,99 posisinya adalah rata-rata; dan skor 3,0-4,0 adalah kuat. Pada sumbu Y untuk matriks EFE, skor 1,0-1,99 adalah rendah; skor 2,0-2,99 adalah sedang; dan skor 3,0-4,0 adalah tinggi. 
Mengenai matriks IE disajikan pada gambar berikut :

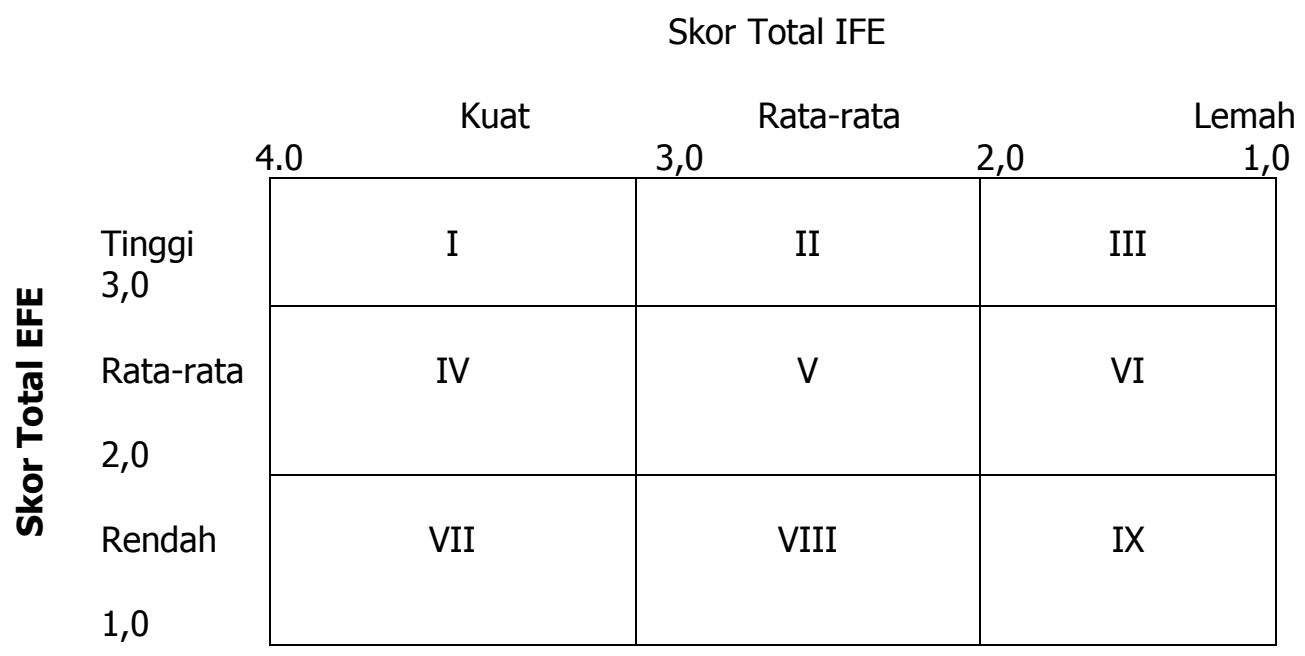

Gambar 1. Matriks Internal Eksternal

Matriks IE memiliki tiga implikasi strategi yang berbeda, yaitu :

a. Sub Bisnis Unit (SBU) yang berada pada sel I, II, atau IV digambarkan sebagai grow dan build. Pilihan alternatif strateginya adalah strategi intensif seperti market penetration, market development, dan product development atau strategi terintegrasi seperti backward integration, forward integration dan horizontal integration.

b. Sub Bisnis Unit (SBU) yang berada pada sel III, V, atau VII dikendalikan dengan strategi-strategi hold dan maintan. Pilihan alternatif strateginya adalah strategi market penetration dan product development.

c. Sub Bisnis Unit (SBU) yang berada pada sel VI, VIII, atau IX dapat menggunakan strategi harvest atau divestiture.

\section{HASIL DAN PEMBAHASAN}

Lingkungan perusahaan akan dianalisis melalui analisis lingkungan internal dan eksternal perusahaan. Analisis faktor internal yang mempengaruhi bauran pemasaran susu kedelai bubuk produksi pabrik susu kedelai Kadungora disajikan pada Tabel 3. 
Peningkatan Pemasaran Susu Kedelai Bubuk Melalui Strategi Bauran: Studi Kasus Pada Pabrik Susu Kedelai Kadungora di Desa Kadungora, Kecamatan Kadungora, Kabupaten Garut (Dini Rochdiani dan Hesty Nurul Utami)

Tabel 3. Ringkasan Faktor Internal Perusahaan yang Mempengaruhi Bauran Pemasaran Susu Kedelai Bubuk Produksi pabrik Susu Kedelai Kadungora

\begin{tabular}{|c|c|c|}
\hline $\begin{array}{c}\text { Faktor } \\
\text { Internal }\end{array}$ & Kekuatan & Kelemahan \\
\hline $\begin{array}{l}\text { Bauran } \\
\text { Produk }\end{array}$ & $\begin{array}{l}\text { - Kualitas produk lebih baik dibandingkan } \\
\text { produk sejenis } \\
\text { - Manfaat kesehatan yang terkandung dalam } \\
\text { produk }\end{array}$ & \\
\hline $\begin{array}{l}\text { Bauran } \\
\text { Harga }\end{array}$ & $\begin{array}{l}\text { - Harga produk terjangkau pelanggan dan } \\
\text { lebih murah dibandingkan harga produk } \\
\text { pesaing }\end{array}$ & \\
\hline $\begin{array}{l}\text { Bauran } \\
\text { Distribusi }\end{array}$ & & $\begin{array}{l}\text { - Perantara pendistribusian produk } \\
\text { masih terbatas, hanya melalui } \\
\text { agen dan retailer }\end{array}$ \\
\hline $\begin{array}{l}\text { Produksi } \\
\text { dan } \\
\text { Penjualan }\end{array}$ & $\begin{array}{l}\text { - Permintaan terus datang dari pelanggan } \\
\text { dan agen, tapi kapasitas produksi terbatas }\end{array}$ & $\begin{array}{l}\text { - Volume penjualan menurun, } \\
\text { selama periode Mei 2005-Mei } \\
2006 \text { hingga } 86,22 \text { persen } \\
\end{array}$ \\
\hline $\begin{array}{l}\text { Sumber } \\
\text { Daya } \\
\text { Keuangan }\end{array}$ & $\begin{array}{l}\text { - Manajer keuangan cukup ahli dalam bidang } \\
\text { akuntansi, sehingga pembukuan keuangan } \\
\text { perusahaan tertata dengan baik dan cukup } \\
\text { lengkap }\end{array}$ & $\begin{array}{l}\text { - Arus kas mengalami } \\
\text { ketidaklancaran terutama mulai } \\
\text { bulan Januari 2006, menyebabkan } \\
\text { kegiatan produksi terhambat dan } \\
\text { mengalami penurunan hingga } \\
91,31 \text { persen. }\end{array}$ \\
\hline $\begin{array}{l}\text { Sumber } \\
\text { Daya } \\
\text { Manusia }\end{array}$ & $\begin{array}{l}\text { - Team work dan loyalitas staf manajemen } \\
\text { dalam perusahaan yang tinggi dan terjalin } \\
\text { hubungan yang erat antar staf karyawan. }\end{array}$ & $\begin{array}{l}\text { - Jumlah staf manajemen } \\
\text { perusahaan hanya lima orang, dan } \\
\text { sering dilakukan rangkap jabatan } \\
\text { dalam struktur organisasi } \\
\text { perusahaan } \\
\text { - Operasionalisasi pelaksanaan } \\
\text { struktur organisasi manajemen } \\
\text { perusahaan yang tidak difungsikan } \\
\text { dengan benar dan orang-orang } \\
\text { yang bertindak sebagai persero } \\
\text { tidak umum terjadi pada sebuah } \\
\text { CV, sehingga banyak } \\
\text { penyimpangan yang terjadi dalam } \\
\text { manajemen organisasi perusahaan }\end{array}$ \\
\hline $\begin{array}{l}\text { Penelitian } \\
\text { dan } \\
\text { Pengemban } \\
\text { gan Produk } \\
\text { (R \& D) }\end{array}$ & $\begin{array}{l}\text { - Penelitian dan pengembangan produk terus } \\
\text { dilakukan dan bekerja sama dengan } \\
\text { berbagai pihak yang mendukung R\&D, } \\
\text { diantaranya dengan laboratorium jurusan } \\
\text { Teknologi Pangan IPB } \\
\text { - Banyak mengikuti seminar dan pelatihan } \\
\text { dalam rangka mendukung kualitas dan } \\
\text { pengembangan produk }\end{array}$ & \\
\hline
\end{tabular}


Analisis faktor eksternal perusahaan yang mempengaruhi bauran pemasaran susu kedelai bubuk produksi pabrik susu kedelai Kadungora disajikan pada Tabel 4.

Tabel 4. Ringkasan Faktor Eksternal Perusahaan yang Mempengaruhi Bauran Pemasaran Susu Kedelai Bubuk Produksi Pabrik Susu Kedele Kadungora

\begin{tabular}{lll}
\hline Faktor Eksternal Peluang Ancaman & A \\
\hline
\end{tabular}

a. Makro Eksternal

\begin{tabular}{lll}
\hline Lingkungan Ekonomi & $\begin{array}{l}\text { - Fluktuasi harga bahan baku } \\
\text { kedelai impor yang sering } \\
\text { digunakan tidak pernah lebih } \\
\text { dari dua hingga tiga persen }\end{array}$ & $\begin{array}{l}\text { - Kenaikan harga bahan } \\
\text { bakar minyak menyebabkan } \\
\text { kenaikan harga jual produk } \\
\text { sebesar 23.08 persen }\end{array}$ \\
\hline Lingkungan Sosial & $\begin{array}{l}\text { - Preferensi pelanggan yang } \\
\text { tinggi terhadap susu kedelai } \\
\text { sebagai produk kesehatan }\end{array}$ & \\
& - Preferensi masyarakat & \\
& terhadap susu bubuk yang & \\
& lebih tinggi dibandingkan & \\
terhadap susu cair & - Perkembangan teknologi \\
ingkungan & & informasi dan teknologi \\
produksi yang sangat cepat \\
seknologi
\end{tabular}


Peningkatan Pemasaran Susu Kedelai Bubuk Melalui Strategi Bauran: Studi Kasus Pada Pabrik Susu Kedelai Kadungora di Desa Kadungora, Kecamatan Kadungora, Kabupaten Garut (Dini Rochdiani dan Hesty Nurul Utami)

b. Mikro Eksternal

\begin{tabular}{|c|c|c|}
\hline Pesaing & $\begin{array}{l}\text { - Kualitas produk lebih baik } \\
\text { dibandingkan produk-produk } \\
\text { pesaing } \\
\text { - Harga produk lebih murah } \\
\text { dibandingkan produk-produk } \\
\text { pesaing }\end{array}$ & $\begin{array}{l}\text { - Pangsa pasar yang } \\
\text { mungkin diambil pesaing } \\
\text { akibat tingkat penjualan } \\
\text { produk per bulan yang } \\
\text { menurun sehingga lebih } \\
\text { rendah dibandingkan } \\
\text { tingkat penjualan salah satu } \\
\text { produk pesaing }\end{array}$ \\
\hline Perantara & $\begin{array}{l}\text { - Hubungan yang baik dengan } \\
\text { pemasok mempermudah } \\
\text { perusahaan memperoleh } \\
\text { bahan baku dan menjaga } \\
\text { kontinuitas produksi }\end{array}$ & $\begin{array}{l}\text { - Agen penyaluran produk } \\
\text { yang tidak bertanggung } \\
\text { jawab dan tidak profesional } \\
\text { dalam menjalin kerjasama } \\
\text { dengan perusahaan } \\
\text { - Pengunduran diri Investor } \\
\text { awal sebagai rekanan } \\
\text { keuangan }\end{array}$ \\
\hline Pelanggan & $\begin{array}{l}\text { - Loyalitas pelanggan untuk } \\
\text { tetap menggunakan produk } \\
\text { yang tinggi }\end{array}$ & \\
\hline
\end{tabular}

Perumusan alternatif strategi pada matriks Eksternal Factors Evaluation (EFE) dapat dijelaskan pada Tabel 5 .

Tabel 5. Matriks Hasil Eksternal Factors Evaluation (EFE)

\begin{tabular}{|c|c|c|c|c|}
\hline \multirow{2}{*}{ No } & Faktor Kunci & Bobot & Rating & Skor \\
\hline & Peluang & $\left(A_{i}\right)$ & $\left(B_{i}\right)$ & $\left(A_{i} \times B_{i}\right)$ \\
\hline 1. & $\begin{array}{l}\text { Kemudahan akses terhadap bahan } \\
\text { baku }\end{array}$ & 0,101 & 4 & 0,404 \\
\hline 2. & Pelanggan setia & 0,115 & 4 & 0,460 \\
\hline 3. & $\begin{array}{l}\text { Cakupan pemasaran susu kedelai } \\
\text { bubuk }\end{array}$ & 0,108 & 3 & 0,324 \\
\hline 4. & $\begin{array}{l}\text { Preferensi pelanggan terhadap susu } \\
\text { kedelai sebagai produk kesehatan }\end{array}$ & 0,103 & 3 & 0,267 \\
\hline \multirow[t]{2}{*}{5.} & $\begin{array}{l}\text { Preferensi masyarakat terhadap } \\
\text { susu bubuk }\end{array}$ & 0,089 & 4 & 0,356 \\
\hline & Ancaman & & & \\
\hline 1. & Penanam modal (investor) & 0,094 & 1 & 0,094 \\
\hline 2. & Agen penyalur susu kedelai bubuk & 0,110 & 3 & 0,330 \\
\hline 3. & Persaingan dalam industri sejenis & 0,082 & 2 & 0,164 \\
\hline 4. & Munculnya teknologi baru & 0,106 & 3 & 0,318 \\
\hline \multirow[t]{2}{*}{5.} & Dukungan dari pemerintah daerah & 0,092 & 2 & 0,184 \\
\hline & Total & 1,000 & & 2,901 \\
\hline
\end{tabular}


Skor total matriks Evaluasi Faktor Eksternal (EFE) diperoleh sebesar 2,901. Artinya perusahaan telah menjalankan strategi bauran pemasaran produk susu kedelai bubuk yang cukup efektif dengan memanfaatkan peluang-peluang yang ada dan menghindari ancaman-ancaman eksternal yang dihadapi perusahaan saat ini. Faktor kemudahan akses terhadap bahan baku, pelanggan setia, cakupan pasar dan preferensi pelanggan merupakan peluang bagi perusahaan untuk memperluas pasar. Namun dalam memperluas pasar tersebut perlu memperhatikan investor yang turut dalam memberikan permodalan kepada perusahaan, agen penyalur susu kedelai bubuk, persaingan, teknologi baru dan dukungan pemerintah.

Perumusan alternatif strategi pada matriks Internal Factors Evaluation (IFE) dapat dijelaskan pada Tabel 6 .

Tabel 6. Matriks Hasil Internal Factors Evaluation (IFE)

\begin{tabular}{|c|c|c|c|c|}
\hline \multirow{2}{*}{ No } & Faktor Kunci & Bobot & Rating & Skor \\
\hline & Kekuatan & $\left(A_{i}\right)$ & $\left(B_{i}\right)$ & $\left(A_{i} \times B_{i}\right)$ \\
\hline 1. & Kualitas produk susu kedelai bubuk & 0,112 & 4 & 0,448 \\
\hline 2. & Harga produk susu kedelai bubuk & 0,086 & 4 & 0,344 \\
\hline 3. & $\begin{array}{l}\text { Penelitian dan pengembangan } \\
\text { produk yang dilakukan perusahaan }\end{array}$ & 0,096 & 3 & 0,288 \\
\hline 4. & $\begin{array}{l}\text { Team work dan loyalitas karyawan } \\
\text { (staf manajemen perusahaan) }\end{array}$ & 0,107 & 3 & 0,321 \\
\hline 5. & $\begin{array}{l}\text { Manfaat kesehatan yang dimiliki susu } \\
\text { kedelai bubuk }\end{array}$ & 0,109 & 4 & 0,436 \\
\hline \multicolumn{5}{|c|}{ Kelemahan } \\
\hline 1. & $\begin{array}{l}\text { Pertumbuhan penjualan produk susu } \\
\text { kedelai bubuk }\end{array}$ & 0,103 & 3 & 0,309 \\
\hline 2. & Kapasitas produksi & 0,099 & 2 & 0,198 \\
\hline 3. & Promosi produk susu kedelai bubuk & 0,102 & 2 & 0,204 \\
\hline 4. & $\begin{array}{l}\text { Pembagian kerja dan manajemen } \\
\text { organisasi perusahaan }\end{array}$ & 0,090 & 3 & 0,270 \\
\hline \multirow[t]{2}{*}{5.} & $\begin{array}{l}\text { Variasi produk susu kedelai bubuk } \\
\text { yang ditawarkan }\end{array}$ & 0,095 & 4 & 0,380 \\
\hline & Total & 1,000 & & 3,198 \\
\hline
\end{tabular}

Skor matriks Evaluasi Faktor Internal (IFE) diperoleh 3,198. Artinya secara internal, strategi bauran pemasaran susu kedelai bubuk produksi Pabrik Susu Kedele Kadungora yang telah dilakukan perusahaan berada pada keadaan yang kuat dan sudah optimal. Kekuatan perusahaan adalah kaitannya dengan kualitas, harga susu kedelai, pengembangan produk, loyalitas karyawan serta manfaat susu kedelai bubuk bagi kesehatan merupakan faktor yang menguatkan perusahaan untuk terus menjalankan dan mengembangkan usahanya.

Berdasarkan matriks Internal-Eksternal (IE), menjelaskan bahwa hasil pemetaan pada sumbu $Y$, skor total rata-rata EFE sebesar 2,901 menunjukkan 
bahwa secara eksternal perusahaan berada pada posisi sedang. Hasil pemetaan pada sumbu $X$, diperoleh hasil skor total IFE sebesar 3,198 menunjukkan bahwa secara internal perusahaan berada pada posisi kuat, karena skornya berada diantara 3,0-4,0.

Posisi Pabrik Susu Kedele Kadungora pada matriks IE berdasarkan hasil pemetaan skor total rata-rata EFE dan IFE menempatkan perusahaan pada sel IV, yang digambarkan sebagai daerah grow dan build. Pilihan strategi untuk sel IV adalah startegi terintegrasi dan strategi intensif. Berdasarkan analisis faktor-faktor internal dan eksternal, alternatif strategi bauran pemasaran yang cocok untuk produk susu kedelai bubuk produksi Pabrik Susu Kedele Kadungora adalah strategi terintegrasi berupa strategi integrasi ke depan (forward integration strategy) dan strategi intensif berupa strategi penetrasi pasar (market penetration strategy). Hasil analisis matriks IE memberikan rekomendasi alternatif strategi bauran pemasaran untuk perusahaan berupa perbaikan strategi distribusi dan strategi promosi.

Strategi integrasi ke depan menghendaki perusahaan mempunyai kemampuan yang besar terhadap pengendalian para distributor atau pengecer yang digunakan perusahaan, bila perlu dengan memilikinya (Husein Umar, 2006: 44). Langkah yang bisa dilakukan perusahaan dalam melaksanakan strategi integrasi ke depan diantaranya dengan mengurangi pendistribusian produk melalui agen dan memperbanyak penjualan produk secara langsung konsumen atau melalui retail. Langkah-langkah ini mungkin dilakukan perusahaan karena berdasarkan analisis pelanggan responden lebih banyak memperoleh produk langsung dari pabrik dan adanya tawaran dari sebuah retailer franchise mini market yang menginginkan agar produk masuk ke pasar mereka.

Strategi penetrasi pasar berusaha meningkatkan pangsa pasar untuk produk melalui upaya pemasaran yang lebih besar, mencakup peningkatan jumlah tenaga penjual atau meningkatkan usaha publisitas (Fred R. David, 2006: 233). Alternatif startegi ini tepat bagi perusahaan, terutama berhubungan dengan strategi promosi.

Rekomendasi perbaikan dalam strategi promosi adalah tepat berdasarkan analisis pelanggan yang menunjukkan bahwa promosi produk yang dilakukan saat ini belum merata dalam menginformasikan dan mempublikasikan produk kepada konsumen di semua wilayah pemasaran. Padahal cakupan pemasaran produk yang sudah luas merupakan peluang untuk mempromosikan produk yang secara kualitas dan harga lebih unggul dibandingkan pesaing-pesainganya.

Langkah yang dapat dilakukan adalah pengangkatan tenaga penjual, karena selama ini perusahaan belum memiliki tenaga penjual, karena tenaga penjual yang digunakan selama ini adalah staf manajemen perusahaan yang merangkap tugas sebagai tenaga pemasaran. Usaha peningkatan publisitas produk dapat dilakukan, mengingat saat ini perusahaan lebih banyak melakukan kegiatan promosi melalui pameran dagang, iklan brosur yang hanya dilakukan untuk daerah pemasaran 
Garut dan Bandung, sedangkan wilayah pemasaran lainnya belum mendapatkan promosi, serta mengandalkan informasi dari mulut ke mulut.

Rekomendasi strategi penetrasi pasar tidak akan dapat dilakukan bila permasalahan keuangan yang dialami perusahaan belum mendapatkan solusi. Belum adanya investor baru yang menanamkan modal pada perusahaan merupakan faktor ancaman eksternal paling besar yang juga mempengaruhi kelacaran bauran pemasaran produk. Jadi selama perusahaan belum mendapatkan investor baru, permasalahan keuangan yang berdampak pada ketidaklancaran modal kerja produksi dan kelancaran bauran pemasaran, diantaranya usaha peningkatan pangsa pasar melalui penggunaan tenaga penjual dan peningkatan usaha publisitas yang memerlukan biaya yang besar tidak dapat dilakukan.

\section{SIMPULAN}

1. Bauran pemasaran yang dilakukan pengolah agroindustri biji kedelai Pabrik Susu Kedelai Kadungora untuk produk susu kedelai bubuk meliputi kualitas produk yang tinggi meskipun pilihan variasi produk hanya satu macam, penetapan harga produk dengan metode standard mark-up pricing merupakan harga yang terjangkau konsumen dan memiliki daya saing tinggi, penggunaan agen distributor dengan tipe saluran distribusi konvensional menimbulkan masalah yang menyebabkan ketidaklancaran arus kas, serta kegiatan promosi produk yang terbatas hanya melalui promosi penjualan berupa pameran dagang, iklan melalui brosur, dan system word of mouth dari agen kepada konsumen

2. Strategi integrasi dan strategi intensif dapat dilakukan perusahaan dengan terlebih dahulu melakukan strategi perbaikan manajemen organisasi perusahaan, karena strategi integrasi harus dilakukan secara terintegrasi baik integrasi ke depan maupun integrasi ke belakang dan strategi inensif harus dilakukan secara terpadu, yang semuanya dapat terlaksana bila manajemen organisasi badan hukum perusahaan telah tertata dengan benar dan rapi.

\section{UCAPAN TERIMA KASIH}

Terima kasih kepada pimpinan dan seluruh karyawan Pabrik Susu Kedelai Kadungora serta pimpinan dan seluruh staf Dinas Perindustrian Kabupaten Garut dan aparat Kecamatan Kadungora Kabupaten Garut yang telah membantu penelitian ini.

\section{DAFTAR PUSTAKA}

Cravens, W., David. 2000. Strategic Marketing. Sixth Edition. International Edition. Irwin McGraw-Hill.North America.

David, R. Fred. 2006. Manajemen Strategis: Konsep, Edisi 10 Buku 1. Salemba Empat : Jakarta. 
Peningkatan Pemasaran Susu Kedelai Bubuk Melalui Strategi Bauran: Studi Kasus Pada Pabrik Susu Kedelai Kadungora di Desa Kadungora, Kecamatan Kadungora, Kabupaten Garut (Dini Rochdiani dan Hesty Nurul Utami)

Djaslim Saladin. 2005. Unsur-Unsur Inti Pemasaran dan Manajemen Pemasaan. Mandar Maju : Bandung.

Djaslim Saladin. 2003. Manajemen Strategi dan Kebijakan Perusahaan. Linda Karya: Bandung.

Freddy Rangkuti. 2005. Analisis SWOT Teknik Membedah Kasus Bisnis. PT Gramedia Pustaka Utama: Jakarta.

Husein Umar. 2006. Strategic Management in Action. PT Gramedia Pustaka Utama: Jakarta. 